\title{
Studying of the Factors Affecting on the Mutual Fund by Individual Investor in Iran, Malaysia, Turkey and US
}

\author{
Haniyeh Amiri ${ }^{1} \&$ Ana Maria Gil-Lafuente ${ }^{1}$ \\ ${ }^{1}$ Department of Economics and Business Organization, University of Barcelona, Spain \\ Correspondence: Haniyeh Amiri, Department of Economics and Business Organization, University of Barcelona, \\ Spain. E-mail: amiri.hany@gmail.com/amgil@ub.edu
}

Received: March 27, 2016

Accepted: May 8, 2016

Online Published: July 21, 2016

doi:10.5539/mas.v10n9p218

URL: http://dx.doi.org/10.5539/mas.v10n9p218

\begin{abstract}
This study examines the main criteria of domestic investors in mutual funds selection behavior and evaluates their performance and with a survey method and using a questionnaire, the behavior of domestic investors in selection of mutual fund was evaluated. Factor analysis along with Multinomial Logistic Regression was used to test the hypotheses of the research. The Findings of the study indicate that there are 7 major factors that influence different types of investors in mutual funds selection behavior. These include: inherent characteristics of the fund, image reputation of fund, flexibility to facilitate the investment, performance, popularity, transparency and non-cash benefits. Another important aspect of this study is analysis impressibility the different groups of investors (professional, ambitious, moderate, conservative and cautious) towards these seven factors. The results of this analysis give us what is different between professional investors and other kinds of investors in the selecting of mutual funds.
\end{abstract}

Keywords: behavioral finance, mutual funds, Iran funds, behavioral biases, factor analysis

\section{Introduction}

Consumer behavior from the marketing world and financial economics viewpoint has created the exciting area of behavioral finance for study and research. (Shiller, 2003; Daniel et al., 2002; Hoffmann et al., 2013). Analysts seem to treat financial markets as an aggregate of statistical observations, technical and fundamental analysis. A rich view of research waits this sophisticated understanding of how financial markets are also affected by the 'financial behavior' of investors. Mutual funds are raised as a financial tools that it can carry out these goals and enter retail investors into the area of national economy. We examine main criteria considered by people in the selecting of MFs. Shefrin and Statman (1993) provide a behavioral framework that explains the popularity of some financial products and offer tools for the design and marketing of new ones. They suggest admitting behavioral elements.

The term 'product' is used because MF is not merely to park investor's savings but schemes are 'tailor made' to cater to investor's needs, whatever is their age, financial position, risk tolerance and return expectations. There are not many studies about the behavior patterns of domestic investors. Behavior of investors in the capital market is largely influenced by the 'their expectations' and these 'expectations' of the investors are influenced by their "perception". However, in the financial literature, there are no models which explain the influence of these "perceptions" and "beliefs" on "Expectations" and "Decision Making". Because of our own inability to understand the sources of motivations and the basis of these expectations we tend to ignore them. No doubt, reality is so complex that trying to fit an individual investor's beliefs into a model is impossible. But, to a certain extent, we can borrow concepts from social psychology (Shiller) where behavioral patterns, rational or irrational, are developed and empirically tested. In a portfolio choice example, investors overestimate their return and exhibit a preference for skewness; in general equilibrium, investors' prior beliefs are endogenously heterogeneous. Brunnermeier and Parker (2005) explain in a consumption-saving example, consumers are both overconfident and overoptimistic

On the same lines, we can develop certain models to test the financial behavior to the extent of the availability of explanatory variables. Such models can help MFs managers to understand how and why some behaviors are observed in investor. 
The criteria of individual investors for selection of MFs are not available in many studies, and most of the available studies in this area are related to individual investors' behavior in purchase of stock. Furthermore, finding studies that make a comparative analysis on the status of funds in different countries is extremely difficult. Hence, this study tries to carry out a review on status of MFs in three countries Iran, Malaysia, Turkey and US and then the survey examines the behavior of domestic investors in Fund selection behavior.

The remainder of the paper is organized as follows. Section 2 contains a description of the findings before. The study has classified stages of research in two main steps; In the first step, it analyzes the status of MFs in the sample countries for getting information, in the second step, survey assesses the state of internal MFs to know what savings avenue preference ; all are developed in Section 3. The method is presented in Section 4, MLR is employed to seek a relationship between Fund qualities that affect selection of MFs and types of investors. While findings of Mutual fund in US, Turkey, Malaysia and Iran are discussed in Section 5. Finally, Section 6 concludes and provides implications of this study.

\section{Review of Literature}

Bailey and Kumar (2010) examined the effect of behavioral biases on the mutual fund choices of a large sample of U.S. discount brokerage investors and reported that behaviorally-biased investors typically make poor decisions about fund style and expenses, trading frequency, and timing, resulting in poor performance.

McInishand and Srivastava (1984) indicate that specific demographic characteristics are not particularly useful in differentiating among investors holding divergent opinions. The empirical results of evaluating the risk adjusted performance of US - based international equity funds by Elton et al. (1996) shows that the funds with the highest average returns may lose their attractiveness to investors once the degree of risk embedded in the fund has been factored into the analysis.

Cheng Ru et al. (2008) find that the most important criteria of mutual fund performance for investors are the mutual fund style.

Ranganathan (2006) analyzes funds selection behavior among retail investors with many factors related to the MFs, among of these factors "fund performance" has the greatest impact on selection of MFs by an investor.

Gupta and Jithendranathan (2012) show retail investors prefer less risky investments compared to wholesale investors and have lower preference for overseas investments.

Surveying institutional investors in the United States during 1981-2002 indicates they have added significant value by generating excess returns after controlling for underlying portfolio risk factors (James \& Karceski, 2006).

Uninformed investors preferentially select funds that suit their investment objectives, as they cannot evaluate each product themselves. Thus, their performance depends significantly on the quality of their fund distributors' product portfolios (Baek et al., 2015). Azeez and Yonezawa (2006) found that four different risk factors significantly influence expected returns during each of the sample periods including money supply, inflation, exchange rate, and industrial production.

Nain and Tong (2013) show that the commonly observed correlation between institutional investor ownership and the success of mergers is partly driven by active stock picking.

\section{Methodology}

\subsection{Multinomial Logistic Regression}

Multinomial Logistic Regression (MLR) can be used to predict a dependent variable on the basis of independent variables and to determine the percent of variance in the dependent variable explained by the independents variables; Hosmer et al. (1989) say to rank the relative importance of independents variables and to assess interaction effects. Malhotra (1999) indicates many real world business situations require classification decisions that must often be made on the basis of judgment and past performance. In his study provides input to managers who make such decisions on a routine basis, by multinomial logistic regression analysis (MNL). Application of the decision framework to an actual retail department store data shows that it is most useful in those cases where uncertainty is high and a priori classification cannot be made with a high degree of reliability. Bae (2003) shows a new approach to evaluate contagion in financial markets by using a multinomial logistic regression model, the measure of contagion captures the coincidence of extreme return shocks across countries within a region and across regions, and finds that contagion is predictable and depends on regional interest rates, exchange rate changes, and conditional stock return volatility. The risk capacity of an investor also needs to be understood thoroughly for classifying investors'groups. Table 2 gives the classification of investors' groups (Tamiz et al., 
2013; Garman \& Forgue, 2014). In this study, MLR was employed to seek a relationship between Fund qualities that affect selection of MFs and types of investors.

Table 1. Classification of Investor Groups

\begin{tabular}{llll}
\hline & Investor Types & Risk Profile & Expectations \\
\hline$D_{1}$ & Professional & Takes Necessary Risks & Maximum Return \\
$D_{2}$ & Ambitious & Highly Risk & Taking High Short Term Returns \\
$D_{3}$ & Moderate & Comfortable Levels of Risk & Good, Steady Return \\
$D_{4}$ & Conservative & Risk Averse & Regular Income rather than Capital Gains \\
$D_{5}$ & Cautious & Extremely Risk & Averse Minimum Return/ Capital Preservation \\
\hline
\end{tabular}

To classify the large number of Fund Qualities into smaller number of factors with common constructs, using Principal Component Analysis, Factor Analysis was applied. 7 Principal Components out of 24 fund qualities were extracted and subsequently named. An important part of Factor Analysis is to generate Factor scores for each case or individual survey respondent. Factor scores reflect the importance or lack of importance of each component to each respondent. In the present study Anderson-Rubin (AR) Factor scores were obtained for each respondent. The AR method of deriving Factor scores generates uncorrelated scores with zero mean and unit standard deviation.

The latter acted as the dependent variable in the regression procedure and factor scores were the independent variables. The types of investors, in this study constitute a categorical dependent variable. Additionally, MLR permits in dependent variables that may be factors or covariates. The covariates must be continuous and that is the case for the survey respondents AR Factor scores. Some results of MLR for Fund qualities affecting MF Selection by types of investors are tabulated in table 2 .

Table 2. Multinomial Logistic Regression Analysis, Fund Qualities Affecting MF/Scheme Selection vs. Types of Investors

\begin{tabular}{lllll}
\hline Model & $-2 \log$ likelihood & Chi-square & Dfsi & \\
\hline Intercept & 234.086 & & & \\
Final & 168.736 & 65.350 & 28 & 0.000 \\
\hline
\end{tabular}

A well-fitting model is significant at .05 levels or less than that. In this study, the 'Sig' value in the 'Final' row in the 'Model Fitting Information' is .000 , which proves the analysis to be a well-fitting model.

Table 3. Pseudo R-Square

\begin{tabular}{ll}
\hline Cox and Snell & 0.628 \\
\hline Nagelkerke & 0.466 \\
McFadden & 0.578 \\
\hline
\end{tabular}

Table 4. Goodness-to-fit

\begin{tabular}{llll}
\hline & Chi-square & df & Sig. \\
\hline Pearson & 382.218 & 308 & .005 \\
Deviance & 167.350 & 308 & 1.000 \\
\hline
\end{tabular}


Table 5. Likelihood Ratio Tests

\begin{tabular}{lllll}
\hline Effect & Reduced Model & Chi-Square & df & Sig. \\
\hline Intercept & 225.696 & 56.960 & 4 & .000 \\
1.Intrinsic qualities of the product & $182.612(\mathrm{a})$ & 13.875 & 4 & .004 \\
2.Portfolio Management & $175.632(\mathrm{a})$ & 6.896 & 4 & .004 \\
3.Flexibleinvestment facilities & $173.862(\mathrm{a})$ & 5.126 & 4 & .005 \\
4.research group & $174.419(\mathrm{a})$ & 5.683 & 4 & .004 \\
5.Reputation & $173.671(\mathrm{a})$ & 4.935 & 4 & .000 \\
6.Preliminary Disclosure & $175.339(\mathrm{a})$ & 6.602 & 4 & .000 \\
7.Fringe Benefits & $187.538(\mathrm{a})$ & 18.802 & 4 & .001 \\
\hline
\end{tabular}

The results of Goodness-of-Fit; is based on the null hypothesis (in a null hypothesis the effects of all parameters on each other is zero.); reveal that the Model has a good level of Fitness. Significant levels of these two tests are more than 0.05 , and then we conclude that the model combination of independent variables and dependent variables is very well. It means that, the independent variables can provide a fairly accurate variance for dependent variable.

Cox/Snell, Nagelkerke and Mcfaddenpsuedo $\left(\tau^{2}\right)$ co-efficient are $62.8 \%, 46.6 \%$ and $57.8 \%$.These three coefficients- that are between 0 and 1- Show that how much of variance in the dependent variable is explained by the independent variables that we insert in the model. Therefore, the more the values of these coefficients are closer to 1 , the more we are confident that model is more efficient inexplaining the dependent variable. A scrutiny of "Likelihood Ratio Tests" reveals that, in the present study, Factor 7 (Fringe Benefits), Factor 1(Intrinsic qualities of the product), and Factor 2 (Portfolio Management) have proved significant among other extracted factors, as their $\mathrm{p}$ value is $\leq 0.05$.

The result of Parameter Estimates exploded difference between professional investors (D1) and other types of investorsin Mutual Fund/Scheme selection behaviour.

"Wald parameter" refers to the significance of all independent variables (7 element of Factor Analysis) that are into to the model. A well-fitting variable for model is significant at .05 levels or lesser. In this table, we omitted all of independent variables that their significant level was $0>0.05$.The " $\operatorname{Exp}(\mathrm{B})$ " indicates that what happens for dependent variable if the independent variable is changed.In other words, it shows amount of changein dependent variable (investor groups) versus the change of independent variable, and also, " $\mathrm{B}$ " indicates the side of the changes. Variables with positive coefficient increase probability occurrence of phenomenon and inverse.

On the basis of Parameter Estimates, comparison of fund selection behavior of professional investors $\left(D_{1}\right)$ with cautious investors $\left(D_{5}\right)$ reveal that cautious investors have more emphasis on 4 factors (Portfolio Management, Flexible investment facilities, Preliminary Disclosure, Fringe Benefits) in MF selection behavior toward the professional investors.

Other important results of MLR analysis is related to Parameter Estimates given in Table 6.

Table 6. Results of Multinomial Logistic Regression Analysis (Parameter Estimates) - different between Professional investors and other types of investors that affect Mutual Fund/Scheme Selection

\begin{tabular}{lllll}
\hline Difference in fund selection & Attributes leading at 2.5 or less & Exp (B) & Wald (sig) & B \\
\hline 1.Between $D_{1}$ and $D_{5}$ & & & & \\
factor $D_{1}<D_{5}$ & Portfolio management & $5.5 E+21$ & 0 & 50.054 \\
& Flexible investment facilities & 2.14 & 0 & 9.972 \\
Factors $D_{1}<D_{5}$ & Preliminary Disclosure & 3.19 & 0 & 14.978 \\
& & & & 47.953 \\
& Fringe Benefits & $6.7 E+20$ & 0 & \\
\hline
\end{tabular}




\begin{tabular}{|c|c|c|c|c|}
\hline factor $D_{1}<D_{4}$ & Fringe Benefits & 53.439 & 0.003 & 3.979 \\
\hline \multirow[t]{4}{*}{ Factors $D_{1}<D_{4}$} & Intrinsic qualities of the product & & & -3.180 \\
\hline & Portfolio Management & 0.042 & 0.002 & -1.813 \\
\hline & Research group & 0,163 & 0.017 & -1.394 \\
\hline & & 0.248 & .056 & \\
\hline \multicolumn{5}{|c|}{ 3.Between D1 and D3 } \\
\hline factor $D_{1}<D_{3}$ & Preliminary Disclosure & 2.407 & 0.044 & 0.878 \\
\hline \multirow[t]{3}{*}{ Factors $D_{1}<D_{3}$} & Intrinsic qualities of the product Research group & & 0.11 & \\
\hline & & 0.166 & 0.35 & -1.797 \\
\hline & & 0.260 & & -1.348 \\
\hline \multicolumn{5}{|l|}{ Between $D_{1}$ and $D_{2}$} \\
\hline factor $D_{1}<D_{2}$ & Preliminary Disclosure & 3.171 & 0.18 & 1.154 \\
\hline \multirow[t]{3}{*}{ Factors $D_{1}<D_{2}$} & Intrinsic qualities of the product Reputation & & & $-1.466-0.868$ \\
\hline & & 0.231 & 0.028 & \\
\hline & & 0.420 & 0.046 & \\
\hline
\end{tabular}

\subsection{Data Collection}

The information needed for us also include two main parts. In the first part(Understudy countries), we got the necessary information through the annual reports of Stock markets, Fact books of MFs, previous research and other useful web sites. The unit of observation and analysis of this survey is the individual present retail investor. Our definition of present retail investor is "An individual who has currently invested in any MF scheme and it does not include high net-worth individuals, those who earn above 6,000,000 dollars per annum, and institutions. The required data was collected through a pre-tested questionnaire which was administered on a sample of 300 educated present retail investors. This sample was selected due to the time and financial constraints.

\section{Findings of the Study}

Findings of the study are revealed in the following section:

\subsection{Mutual Fund in Understudy Countries}

\subsubsection{Mutual Fund in US}

American MFs play an important role in the domestic economy and global financial markets. This company managed about 18.2trillion dollars for an early 90.4 million Americans (53.2 million U.S. households) in the end of 2014. This amount encompasses 54 percent of the total assets owned by MFs in the world wide. America's MFs employ their capital in the securities markets throughout the world and they are considered as the largest group of investors in the stock market, commercial paper and municipal bonds. At the end of 2014 about $43 \%$ of Americans households' invested in the mutual funds.In1980, this amount was near 5.7\%. This indicates growing confidence of investors towards the MFs. Among all households that were invested in the MFs, $76 \%$ emphasized that saving for retirement has been their main purpose of investment.

\subsubsection{Mutual Fund in Turkey}

Two different kinds of MFs, (type A and type B), exist in the Turkish capital market. Type A of MFs requires to invest at least $125 \%$ of their assets in the shares issued by Turkish companies. While, MFs that are classified as group B do not have such commitments and obligations. These two main groups of MFs are divided into17 smaller sections based on their portfolio. At the end of 2014, the total number of funds in Turkey was 369 . Among all of them, Variable Funds with 120, Money Market Funds with 53 and Bond Funds with 45 constitute the majority of MFs groups, which includes $59 \%$ of funds. In 2014, approximately 6.2 million people invested in the Turkey MFs and $67 \%$ of deposits were related to foreign investors. MFs are also included in $2.9 \%$ of gross 
domestic product (GDP) of Turkey.

\subsubsection{Mutual Fund in Malaysia}

Net Asset Value (NAV) of mutual funds industry in Malaysia, compared to 39 billion dollars in previous year, was 56billion dollars. This $41 \%$ increase, or 17billion dollars, is attributed to net sales in unit trusts coupled with asset price that increases when stock markets are recovered. Overall, growth statistics for the MFs industry in Malaysia as follows:

Net Asset Value (NAV) of MFs increased to 81 billion dollars

Number of MFs account holders increased to 17,415,418 million at the end of 2014.

The mutual funds industry's NAV represents $20.77 \%$ of Bursa Malaysia's market capitalization

Net Asset Value (NAV) of Islamic mutual funds grew and reached to 11.01 billion dollars.

Out of the total 626 funds in the industry, conventional funds represented 436 funds while the Islamic funds accounted for 190 funds

\subsection{Mutual Fund in Iran}

There were 136 MFs in the stock market of Iran. These funds managed professionally the capital of 168.842 individual investors in the stock market. NAV 2.072 million dollars.Since most Iranian, investors lack professional knowledge of optimal investment, they can depòsit their capital in such funds that are managed by professionals

\section{Classified Variables}

We have classified stages of research in two main steps. In the first step, we analyze the status of MFs in the sample countries for getting information such as: the number of funds and their investors in that countries, variety of investors, preferences of investors for direct stock purchase or investment in the funds.

In the second step respondents were asked to rank their preferences on a scale, 5 point scale ranging from Highly Important (5) to Not at all Important (1). Using Principal Component Analysis, data for each of the 3 sub-groups were tested under factor analyses. To identify the factors that influence the investors' fund/scheme selection, 24 variables were identified through a brainstorming session and the evidences were collected from past research prior to the construction of the questionnaire at the time of the pilot study.

Based on theory, past research, and judgment of the researcher, the factors that could influence the investors in their selection of Mutual Funds/schemes was first grouped into 3 major factors - Fund/Scheme qualities, fund sponsor qualities and the expected investor services. The aim was to identify factors in the sub-groups which turn out to be significant in the fund selection. The 24 identified variables were classified under the appropriate group as follows:

A) Fund Related Qualities

$A_{1}$ Fund's/Scheme's performance record

$\mathrm{A}_{2}$ Fund's/Scheme's reputation or brand name

$\mathrm{A}_{3}$ Scheme's expense ratio

$\mathrm{A}_{4}$ Scheme's portfolio of investments

$\mathrm{A}_{5}$ Reputation of scheme(s), portfolio manager(s)

$\mathrm{A}_{6}$ Withdrawal facilities

$\mathrm{A}_{7}$ Favorable rating by a rating agency

$\mathrm{A}_{8}$ Innovativeness of the Scheme

$\mathrm{A}_{9}$ Products with tax benefits

$\mathrm{A}_{10}$ Entry and Exit load

$\mathrm{A}_{11}$ Minimum initial investment

B) Fund Sponsor Qualities

$B_{1}$ Reputation of a sponsoring firm

$B_{2}$ Sponsor has a recognized brand name

$B_{3}$ Sponsor's expertise in managing money 
$B_{4}$ Sponsor has a well-developed Agency Net Work/Infrastructure

$B_{5}$ Sponsor's past performance in terms of risk and return

C) Investor Related Services

$C_{1}$ Disclosure of investment objectives, method and periodicity of valuation in advertisement

$C_{2}$ Disclosure of periodicity of valuation in the advertisement

$C_{3}$ Disclosure of the method and periodicity of the scheme's sales and repurchase in the offer documents

$C_{4}$ Disclosure of NAV on every trading day

$C_{5}$ Disclosure of deviation of the investments from the original pattern

$C_{6}$ Mutual fund investors' grievance redressal machinery.

$C_{7}$ Fringe benefit like free insurance, free credit card, loans on collateral, tax benefits.

$C_{8}$ Preferred MF to avoid problems, i.e., bad deliveries, and unnecessary follow up with brokers and companies.

\section{Findings and Results}

\subsection{Influence of Product Qualities on Selection of Fund}

The 11 fund related variables were analyzed for their importance. Hence, to identify the investor's underlying fund selection criteria, they are grouped into specific market segments to enable the designing of the appropriate marketing strategy.

Thus, using Principal Component Analysis, Factor Analysis was done. Bartlett's test of sphericity and Kaiser-Meyer Olkin's (KMO) measure of sampling adequacy were used to examine the appropriateness of factor analysis. The approximate chi-square statistics is 311.425 with 45 degrees of freedom which is significant at 0.05 level. The KMO statistic $(0.684)$ is also large $(>0.5)$. Hence factor analysis is considered as an appropriate technique for further analysis of data. Results of Principal Component Analysis for Product related qualities are tabulated in table 7 .

Table 7. Results of Principal Component Analysis

\begin{tabular}{|c|c|c|c|c|c|c|}
\hline \multicolumn{3}{|c|}{ Communalities } & \multicolumn{4}{|c|}{ InitialEigenValues } \\
\hline Variable & Initial & Extraction & Factor & Eigenvalue & $\%$ of variance & Cumulative $\%$ \\
\hline$A_{1}$ & 1.000 & 0.509 & 1 & 4.006 & 26.420 & 36.420 \\
\hline$A_{2}$ & 1.000 & 0.570 & 2 & 1.386 & 12.602 & 49.023 \\
\hline$A_{3}$ & 1.000 & 0.486 & 3 & 1.061 & 9.648 & 58.671 \\
\hline$A_{4}$ & 1.000 & 0.690 & 4 & .886 & 8.055 & $66 . .725$ \\
\hline$A_{5}$ & 1.000 & 0.534 & 5 & .807 & 7.340 & 74.066 \\
\hline$A_{6}$ & 1.000 & 0.751 & 6 & .675 & 6.137 & 80.203 \\
\hline$A_{7}$ & 1.000 & 0.428 & 7 & .629 & 5.720 & 85.923 \\
\hline$A_{8}$ & 1.000 & 0.470 & 8 & .476 & 4.324 & 90.247 \\
\hline$A_{9}$ & 1.000 & 0.710 & 9 & .441 & 4.011 & 94.258 \\
\hline$A_{10}$ & 1.000 & 0.690 & 10 & .342 & 3.113 & 97.370 \\
\hline$A_{11}$ & 1.000 & 0.616 & 11 & .289 & 2.630 & 100.000 \\
\hline
\end{tabular}

Note. Bartlett's Test of sphericity; Approximate chi-square $=291.236 ; \mathrm{df}=55 ;$ significance $=0.000$; Kaiser-Meyer-Olkin Measure of Sampling Adequacy $=.785$. 


\begin{tabular}{|c|c|c|c|c|c|c|c|c|}
\hline \multicolumn{6}{|c|}{ Extraction sums of squares loadings } & \multicolumn{3}{|c|}{ Rotation Sums of Squared Lo } \\
\hline Factor & Eigen value & \multirow{2}{*}{\multicolumn{2}{|c|}{$\begin{array}{l}\% \text { of variance } \\
36.420\end{array}$}} & Cumulative & & \multirow{2}{*}{\multicolumn{2}{|c|}{$\begin{array}{l}\text { Eigen value } \\
20.888\end{array}$}} & \multirow{2}{*}{$\begin{array}{l}\text { \%of var Cumu } \\
20.888\end{array}$} \\
\hline 1 & 4.006 & & & $36.420 \quad 2$. & & & & \\
\hline 2 & 1.386 & \multicolumn{2}{|l|}{12.602} & 49.023 & & \multicolumn{2}{|c|}{19.223} & 0.111 \\
\hline \multirow[t]{14}{*}{3} & 1.061 & 9.648 & & 58.671 & & 18.5 & & 8.671 \\
\hline & & \multicolumn{3}{|c|}{ Factor Matrix } & \multicolumn{4}{|c|}{ Rotated Factor Matrix } \\
\hline & Variable & Factor 1 & Factor 2 & Factor 3 & $\mathrm{Fac}$ & ctor 1 & Factor 2 & Factor 3 \\
\hline & $A_{1}$ & 0.618 & -0.357 & 0.000 & 0.5 & & 0.438 & 0.009 \\
\hline & $A_{2}$ & 0.538 & -0.231 & 0.477 & 0.7 & & -0.006 & 0.155 \\
\hline & $A_{3}$ & 0.681 & -0.057 & -0.138 & 0.3 & & 0.523 & 0.272 \\
\hline & $A_{4}$ & 0.724 & -0.184 & 0.363 & 0.7 & & 0.184 & 0.269 \\
\hline & $A_{5}$ & 0.572 & -0.424 & -0.163 & 0.4 & & 0.551 & -0.099 \\
\hline & $A_{6}$ & 0.618 & -0.104 & -0.598 & 0.0 & & 0.854 & 0.122 \\
\hline & $A_{7}$ & 0.565 & -0.252 & 0.211 & 0.6 & & 0.222 & 0.107 \\
\hline & $A_{8}$ & 0.595 & 0.050 & -0.338 & 0.1 & & 0.607 & 0.285 \\
\hline & $A_{9}$ & 0.576 & 0.580 & -0.206 & -0 . & .049 & 0.338 & 0.746 \\
\hline & $A_{10}$ & 0.592 & 0.559 & 0.163 & 0.1 & & 0.114 & 0.799 \\
\hline & $A_{11}$ & 0.532 & 0.513 & 0.266 & 0.2 & & 0.007 & 0.747 \\
\hline
\end{tabular}

Because only variables with Eigen values greater than one (Kaiser's criterion) will remain in the Model, we can infer that $36.420 \%$ of variance is explained by factor $1 ; 12.602 \%$ of variance is explained by factor 2 and $96.48 \%$ of variance is explained by factor 3 and all three factors together contributed to $57.671 \%$ of variance.

Factor loadings are very high in case of factor 1 (all of 11 variables have factor loading $>0.5$ ). It reveals that all of the variables are clubbed into one factor. But on the basis of theory, we can infer that there must be more than one factor. Therefore, Varimax Rotation was done to obtain factors that can be named and interpreted. Under Varimax Rotation only4 out of 11 variables have factor loadings $>0.5$ for factor 1 .

On the basis of Varimax Rotation with Kaiser Normalization 3 factors have emerged. Each factor is constituted of all those variables that have factor loadings greater than or equal to 0.5

Thus $A_{1}, A_{2}, A_{4}$ and $A_{7}$ constituted the first factor. The researcher conceptualized this factor as "Intrinsic Product Qualities" $A_{3}, A_{5}, A_{6}$ and $A_{8}$ constituted the second factor and this was conceptualized as "Portfolio Management"; $A_{9}, A_{10}$ and $A_{11}$ constituted the 0rd factor and this was conceptualized as "Flexible investment facilities" factor.

Thus, after rotation, factor 1 (Intrinsic Product Qualities) accounts for $20.888 \%$ of the variance; factor 2 (Portfolio Management) accounts for $19.223 \%$ of variance and factor 3 (Flexible investment facilities) accounts for $18.559 \%$ of variance and all 0 factors together explain for $58.671 \%$ of variance. The identified factors with the associated variable and factor loadings are given in Table 8. 
Table 8. Identification of product related factors in fund selection

\begin{tabular}{lcll}
\hline Intrinsic qualities of the product & $A_{1}$ & Fund's/Scheme's performance record & 0.564 \\
\hline & $A_{2}$ & Fund's/Scheme's performance record & 0.739 \\
& $A_{4}$ & Scheme's expense ratio & 0.764 \\
& $A_{7}$ & Scheme's portfolio of investments & 0.606 \\
& $A_{3}$ & Reputation of scheme(s), portfolio manager(s) & 0.523 \\
& $A_{5}$ & Withdrawal facilities & 0.551 \\
& $A_{6}$ & Favorable rating by a rating agency & 0.854 \\
& $A_{8}$ & Innovativeness of the Scheme & 0.607 \\
Flexible investment facilities & $A_{9}$ & Products with tax benefits & 0.746 \\
& $A_{10}$ & Entry and Exit load & 0.779 \\
& $A_{11}$ & Minimum initial investment & 0.747 \\
\hline
\end{tabular}

\subsection{Influence of Fund Sponsor Qualities on Selection of Fund}

The six sponsors' related variables were analyzed for their importance.

Hence, to identify the investor's sponsor related qualities which influence his fund/scheme selection, so as to enable the sponsors to develop the identified qualities. Its results for sponsor related qualities are tabulated in Table 9.

Table 9. Results of Principal Component Analysis

\begin{tabular}{cllllll}
\hline \multicolumn{6}{l}{ Communalities } & \multicolumn{5}{l}{ Initial Eigen Values } \\
\hline Variable & Initial & Extraction & Factor & Eigen value & \% of variance & Cumulative \% \\
$B_{1}$ & 1.000 & 0.709 & 1 & 3.181 & 63.615 & 63.615 \\
$B_{2}$ & 1.000 & 0.999 & 2 & 0.737 & 14.737 & 78.352 \\
$B_{3}$ & 1.000 & 0.672 & 3 & 0.502 & 10.041 & 88.393 \\
$B_{4}$ & 1.000 & 0.596 & 4 & 0.359 & 7.183 & 95.576 \\
$B_{5}$ & 1.000 & 0.342 & 5 & 0.221 & 4.424 & 100.000 \\
\hline
\end{tabular}

Note. Bartlett's Test of sphericity; Approximate chi-square $=214.485 ; \mathrm{df}=10 ;$ significance $=0.000$; Kaiser-Meyer-Olkin Measure of Sampling Adequacy $=0.801$.

\begin{tabular}{|c|c|c|c|c|c|c|c|}
\hline \multicolumn{2}{|c|}{ Extraction sums of } & \multicolumn{3}{|l|}{ squares loadings } & \multicolumn{3}{|c|}{ Rotation Sums of Squared Loadings } \\
\hline Factor & Eigen value & $\%$ of variance & Cumula & & Eigen value & \%of var & Cumulative \\
\hline 1 & 2.248 & 44.961 & 44.961 & 1.770 & 35.404 & 35.404 & \\
\hline 2 & 1.071 & 21.423 & 66.384 & 1.549 & 30.980 & 66.384 & \\
\hline
\end{tabular}

\begin{tabular}{cllll}
\hline \multicolumn{3}{c}{ factor matrix } & \multicolumn{2}{c}{ Rotated factor matrix } \\
\hline Variable & Factor 1 & Factor 2 & Factor 1 & Factor 2 \\
$B_{1}$ & 0.741 & 0.400 & 0.598 & 0.593 \\
$B_{2}$ & 0.999 & -0.003 & 0.288 & 0.957 \\
$B_{3}$ & 0.540 & 0.617 & 0.748 & 0.337 \\
$B_{4}$ & 0.564 & 0.527 & 0.669 & 0.386 \\
$B_{5}$ & 0.299 & 0.503 & 0.568 & 0.140 \\
\hline
\end{tabular}

Retaining only variables with Eigen Values greater than 1, we can infer that $44.961 \%$ of variance is explained by factor 1 and $21.423 \%$ of variance is explained by factor 2 ; both together contribute to $66.384 \%$ of investors' 
behavior.

A scrutiny of Factor Matrix reveals that factor loadings are very high in case of factor 1 (4 out of 5 variables have factor loading $>0.5$ ). It reveals that $80 \%$ of the variables are clubbed into one factor. But, on the basis of theory we can infer that there must be more than one factor. Therefore, Varimax Rotation was done to obtain factors that can be named and interpreted.

On the basis of Varimax Rotation with Kaiser Normalization, 2 factors emerged. Each factor is constituted of all those variables that have factor loadings greater than or equal to 0.5 . Thus $B_{3}, B_{4}$ and $B_{5}$ constituted the first factor. The researcher conceptualized this factor as "research group"; $B_{1}$ and $B_{2}$ constituted the second factor and this was conceptualized as "Reputation".

Thus, after rotation, factor 2 (research group) accounts for $35.404 \%$ of variance and factor 2 (Reputation) accounts for $30.904 \%$ of variance and together they explain for $66.384 \%$ of variance. The identified factors with the associated variable and factor loadings are given in Table 10.

Table 10. Identification of product related factors in fund selection

\begin{tabular}{lcll}
\hline Research group & $B_{3}$ & Sponsor`s expert in managing money & 0.564 \\
\hline & $B_{4}$ & Sponsor has a well-developed Agency Net Work /Infrastructure & 0.739 \\
& $B_{5}$ & Sponsor `s past performance in terms of risk & 0.764 \\
\multirow{3}{*}{ Reputation } & $B_{1}$ & Reputation of a sponsoring firm & 0.523 \\
& $B_{2}$ & Sponsor has a recognized brand name & 0.551 \\
\hline
\end{tabular}

\subsection{Influence of Investor Services on Selection of Fund/Scheme}

The six investor Services related variables were analyzed for their importance. Hence, to identify the investor services related factor, which influences the investor's fund selection, and to enable the AMCs to develop/maintain/improve the identified services. Results of Principal Component Analysis for investor services related factors are tabulated in Table 11.

Table 11. Results of Principal Component Analysis

\begin{tabular}{|c|c|c|c|c|c|c|}
\hline \multicolumn{3}{|c|}{ Communalities } & \multicolumn{4}{|c|}{ Initial Eigen Values } \\
\hline Variable & Initial & Extraction & Factor & Eigen value & $\%$ of variance & Cumulative $\%$ \\
\hline$C_{1}$ & 1.000 & 0.462 & 1 & 3.109 & 38.861 & 38.861 \\
\hline$C_{2}$ & 1.000 & 0.651 & 2 & 1.385 & 17.316 & 56.177 \\
\hline$C_{3}$ & 1.000 & 0.460 & 3 & 0.898 & 11.223 & 67.400 \\
\hline$C_{4}$ & 1.000 & 0.392 & 4 & 0.812 & 10.153 & 77.553 \\
\hline$C_{5}$ & 1.000 & 0.538 & 5 & 0.541 & 6.759 & 84.313 \\
\hline$C_{6}$ & 1.000 & 0.678 & 6 & 0.473 & 5.912 & 90.224 \\
\hline$C_{7}$ & 1.000 & 0.646 & 7 & 0.436 & 5.449 & 95.673 \\
\hline$C_{8}$ & 1.000 & 0.668 & 8 & 0.346 & 4.327 & 100.000 \\
\hline
\end{tabular}

Note. Bartlett's Test of sphericity; Approximate chi-square $=188.877 ; \mathrm{df}=28 ;$ significance $=0.000$; Kaiser-Meyer-Olkin Measure of Sampling Adequacy $=0.750$.

\begin{tabular}{lllllll}
\hline Factor & Eigen value & \% of variance & Cumulative & Eigen value & \%of var Cumulative \\
\hline 1 & 3.109 & 38.861 & 38.861 & 2.297 & 28.711 & 28.711 \\
2 & 1.385 & 17.316 & 56.177 & 2.197 & 27.466 & 56.177 \\
\hline
\end{tabular}

\begin{tabular}{cllll}
\hline & \multicolumn{2}{l}{ Extraction sums of squares loadings } & \multicolumn{2}{l}{ Rotation Sums of Squared Loadings } \\
\hline Variable & Factor 1 & Factor 2 & Factor 1 & Factor 2 \\
$C_{1}$ & 0.636 & 0.241 & 0.628 & 0.261 \\
\hline
\end{tabular}




\begin{tabular}{lllll}
\hline$C_{2}$ & 0.556 & 0.585 & 0.806 & -0.044 \\
$C_{3}$ & 0.618 & 0.280 & 0.641 & 0.220 \\
$C_{4}$ & 0.472 & 0.412 & 0.626 & 0.024 \\
$C_{5}$ & 0.722 & 0.130 & 0.614 & 0.401 \\
$C_{6}$ & 0.707 & -0.421 & 0.225 & 0.792 \\
$C_{7}$ & 0.580 & -0.556 & 0.040 & 0.803 \\
$C_{8}$ & 0.659 & -0.483 & 0.148 & 0.804 \\
\hline
\end{tabular}

Retaining only variables with Eigen Values greater than 1, we can infer that $38.861 \%$ of variance is explained by factor 1 and $17.316 \%$ of variance is explained by factor 2 ; both together contribute to $56.177 \%$ of behavior.

A scrutiny of Factor Matrix reveals that factor loadings are very high in case of factor 1 ( 7 out of 8 variables have factor loading $(>0.5)$. It reveals that $87 \%$ of the variables are clubbed into one factor. But, on the basis of theory we can infer that there must be more than one factor. Therefore, Varimax Rotation was done to obtain factors that can be named and interpreted.

On the basis of Varimax Rotation with Kaiser Normalization, 2 factors emerged. Each factor is constituted of all those variables that have factor loadings greater than or equal to 0.5 . Thus $C_{1}, C_{2}, C_{3}, C_{4}$ and $C_{5}$ constituted the first factor. The researcher conceptualized this factor as "Preliminary Disclosure" and $C_{6}, C_{7}$ and $C_{8}$, constituted the second factor and this was conceptualized as "Fringe Benefits".

Thus, after rotation, factor 1 (Preliminary Disclosure) accounts for $28.711 \%$ of variance and factor 2 (Fringe Benefits) accounts for $27.466 \%$ of variance and together they explain for $56.177 \%$ variance. The identified factors with the associated variable and factor loadings are given in Table 12.

Table 12. Identification of Service related factors in Fund/Scheme Selection

\begin{tabular}{|c|c|c|c|}
\hline $\begin{array}{l}\text { Preliminary } \\
\text { Disclosure }\end{array}$ & $C_{1}$ & Objective disclosure in advertisements & 0.564 \\
\hline \multirow{7}{*}{ Fringe Benefits } & $C_{2}$ & Disclosure of periodicity of valuation & 0.739 \\
\hline & $C_{3}$ & $\begin{array}{l}\text { Disclosure of the method and periodicity of the schemes sales and } \\
\text { repurchases }\end{array}$ & 0.764 \\
\hline & $C_{4}$ & Daily disclosure of NAV & 0.523 \\
\hline & $C_{5}$ & Disclosure of Deviation of investment & 0.531 \\
\hline & $C_{6}$ & Grievances Redressal Machinery & 0.523 \\
\hline & $C 7$ & Fringe Benefits & 0.551 \\
\hline & $C 8$ & $\begin{array}{l}\text { Prefer MF to avoid problems of bad deliveries and follow up with brokers } \\
\text { and companies }\end{array}$ & 0.542 \\
\hline
\end{tabular}

\section{Conclusions}

To understand the status of MFs in the under study countries; the US, Turkey and Malaysia and Iran, we have classified stages of research in two main steps. In the first step, we analyze the status of MFs; the number of funds and their investors in that countries, variety of investors, preferences of investors.

Second step assesses the state of internal MFs to know what savings preference, fund preference and objectives of investment are, and to identify information sources that influence fund selection and preferred mode of communication. Respondents were asked to rank their preferences on a scale.

By using Principal Component Analysis recognize factors in the sub-groups which turn out to be significant in the fund selection. Multinomial Logistic Regression (MLR) can be used to predict a dependent variable on the basis of independent variables and to determine the percent of variance in the dependent variable explained by the independents variables to rank the relative importance of independents variables and to assess interaction effects.

Then MLR technique was employed to seek a relationship between the Factor scores and types of investors, to indicate statistically important factors that influence the Fund selection behavior of different types of investors.

Futur research, the AMC can then apply this knowledge for developing marketing strategies for all types of investors -present and potential- and also identify significant factors that govern an investors' selection of MFs. The results of the research can also be used by the individual investors for the renovation in their investment 
behavior, so that they will be able to manage their capital in best way.

\section{References}

Azeez, A. A., \& Yonezawa, Y. (2006). Macroeconomic factors and the empirical content of the arbitrage pricing theory in the Japanese stock market. Japan and the World Economy, 18(4), 568-91.

Bae, K. H., Karolyi, G. A., \& Stulz, R. M. (2003). A new approach to measuring financial contagion. Review Of Financial Studies, 16(3), 717-763.

Baek, K., \& Park, Y. S. (2015). Do Market Dominant Fund Distributors Provide Better Performing Funds To Investors? Asia-Pacific Journal Of Financial Studies, 44(3), 421-446.

Bailey, W., Kumar, A., \& Ng, D. (2010). Behavioral biases of mutual fund investors. Management science, 54, 443-459. Annual Report, Capital markets board of Turkey, 2010.

Brunnermeier, M. K., \& Parker, J. A. (2005). Optimal expectations. American Economic Review, 95(4), 1092-1118.

Cheng, R. W., Hsin, Y. C., \& Li, S. W. (2008). A framework of assessable mutual fund performance. Journal of Modelling in Management, 3(2), 125-139.

Daniel, K., Hirshleifer, D., \& Teoh, S. H. (2002). Investor psychology in capital markets: evidence and policy implications. Journal of Monetary Economics, 49(1), 139-209.

Elton, E. J., Gruber, M. J., \& Blake, C. R. (1996). The persistence of risk-adjusted mutual fund performance. Journal of Business, 69(2), 133-157.

Garman, E. T., \& Forgue, R. (2014). Personal Finance. Cengage Learning, Business \& Economics, pp.386.

Gupta, R., \& Jithendranathan, T. H. (2012). Fund flows and past performance in Australian managed funds. Accounting Research Journal, 25(2), 131 - 157.

James, C. H., \& Karceski, J. (2006). Investor monitoring and differencesin mutual fund performance. Journal of banking \& finance, 30, 2787-2808.

Hoffmann, Arvid, O. I., Post, T., Pennings, \& Joost, M. E. (2013). Individual investor perceptions and behavior during the financial crisis. Journal of Banking \& Finance, 37(1), 60-74.

Hosmer Jr., David, W., Stanley, L., \& Rodney, X. S. (1989). Logistic Regression for Matched Case Control Studies (3rd eds.). Applied Logistic Regression, 243-268.

Malhotra, M. K., Sharma, S., \& Nair, S. S. (1999). Decision making using multiple models. European Journal of Operational Research, 114(1), 1-14.

McInish, T. H., \& Srivastava, R. K. (1984). The nature of individual investors' heterogeneous expectations. Journal of Economic Psychology, 5(3), 251-263.

Nain, N., \& Tong, Y. (2013). Mutual fund skill and the performance of corporate acquirers. Journal of Financial Economics, $110(2)$, 437-456.

Ranganathan, \& Kavitha (2006). A Study of Fund Selection Behaviour of Individual Investors Towards Mutual Funds with Reference to Mumbai City. Indian Institute of Capital Markets 9th Capital Markets Conference Paper. Retrieved from http://ssrn.com/abstract=876874 or http://dx.doi.org/10.2139/ssrn.876874

Shefrin, H., \& Statman, M. (1993). Behavioral-Aspects of the Design and Marketing of Financial Products. Financial Management, 22(2), 123-134.

Shiller, R. J. (2003). From Efficient Markets Theory to Behavioral Finance. The Journal of Economic Perspectives, 17(1), 83-104.

Tamiz, M., Azmi, A. R., \& Jones, D. F. (2013). On selecting portfolio of international mutual funds using goal programming with extended factors. European Journal of Operational Research, 226(3), 560-576.

\section{Appendix A}

Table 7. Distribution of Individual Investors by Demographic Factors

\begin{tabular}{lll}
\hline Investor Particulars & $\begin{array}{l}\text { Number of Respondents } \\
(\text { Total =300) }\end{array}$ & Percentage (\%) \\
\hline Sex & & \\
Male & 246 & 82 \\
\hline
\end{tabular}




\begin{tabular}{lll}
\hline Female & 54 & 18 \\
age & & \\
Below 30 & 123 & 41 \\
$31-40$ & 108 & 36 \\
$41-50$ & 42 & 14 \\
Above 50 & 27 & 9 \\
Academic qualification & & \\
Elementary school & 9 & 3 \\
School Final & 63 & 21 \\
Graduate & 135 & 45 \\
Post graduate & 81 & 27 \\
Professional & 12 & 4 \\
Marital Status & & \\
Married & 99 & 33 \\
Unmarried & 201 & 67 \\
Occupation & & \\
Professional & 90 & 30 \\
Salaried & 93 & 31 \\
Business & 87 & 29 \\
Retired & 30 & 10 \\
Annual Income (in Rial) & & \\
Less than 100,000,000 & 118 & 39.34 \\
100,000,001-300,000,000 & 159 & 53 \\
300,000,001-500,000,000 & 22 & 7.34 \\
Above 500,000,000 & 3 & 1 \\
Annual Savings (in Rial) & & \\
Less than 50,000,000 & 195 & 65 \\
50,000,001-100,000,000 & 72 & 24 \\
Above 100,000,000 & 33 & 11 \\
\hline & &
\end{tabular}

\section{Appendix B}

Table 8. Mutual Fund Investment Objective among Present Investors

\begin{tabular}{lll}
\hline Objectives & Weighted Mean Value & Rank \\
\cline { 2 - 3 } Safety & 3.6049 & VI \\
Flexibility & 5.2222 & IV \\
Good Return & 3.7531 & V \\
Liquidity & 3.3333 & VIII \\
Capital Appreciation & 5.6420 & II \\
Tax Benefit & 5.8148 & I \\
Diversification Benefit & 5.2593 & III \\
Professional Management & 3.3334 & VII \\
\hline
\end{tabular}

\section{Appendix C}

Table 9. Communication Mode Preference among Mutual Fund Investors Numbers of respondents

\begin{tabular}{lcr}
\hline & $($ Total $=322)$ & Percentage $(\%)$ \\
\hline automated response & 150 & 50 \\
personally visit the office & 66 & 22 \\
telephone the office & 54 & 18 \\
have no preferences & 15 & 5 \\
No respond & 15 & 5 \\
\hline
\end{tabular}




\section{Copyrights}

Copyright for this article is retained by the author(s), with first publication rights granted to the journal.

This is an open-access article distributed under the terms and conditions of the Creative Commons Attribution license (http://creativecommons.org/licenses/by/3.0/). 